\title{
원가계산방식에 의한 다가구임대주택 해체공사비 예측 Demolition Cost Estimation of Small-size Rental Housing based on the Quantity per Unit Method
}

\author{
박성식 ${ }^{1} \cdot$ 이성복 ${ }^{2} \cdot$ 신상훈 $^{3}$ \\ Seong-Sik Park, Sung-Bok Lee $^{2}$ and Sang-Hoon Shin ${ }^{3}$ \\ (Received September 5, 2011 / Revised October 5, 2011 / Accepted October 19, 2011)
}

\begin{abstract}
요 약
본 연구는 $\mathrm{LH}$ 의 다가구임대주택 철거·신축사업에 대비하여 노후주택에 대한 해체공사비를 합리적 근거에 의하여 예측하는 것을 목표로 한다. 이를 위하여 소형주택 해체공사 수행 현황과 작업 프로세스를 조사하고 공사비 견적전문가 면담을 통해 해체공사비 산정실태를 파악하였다. 아울러 공공 건설공사의 ‘예정가격 산정기준'과 '건설폐기물 처리비 산정기준', 선행연구 및 문헌을 고찰하였다. 연구 결과의 하나로 표준품셈에 기초한 해체공사 원가계산체계와 내역체계 및 관련 일위대가를 제안하고, 이를 활용하여 지상 2 3층 규모의 다가구임대주택에 대한 해체공사 예정가격을 산출하였 다. 산출 결과, 1 개 동당 해체공사비는 18,331 천원, 바닥면적 $\left(\mathrm{m}^{2}\right)$ 기준 104 천원으로 예측되었는데, 세부적으로는 직접 철거비가 14,339 천원동, 폐기 물 위탁처리비는 3,992천원/동 소요될 것으로 나타났다. 연구 결과는 노후 다가구임대주택 철거·신축사업의 예산수립 단계에서 사업비 추정을 위한 기본 자료로 활용될 뿐 아니라, 연구 제안한 해체공사 원가계산체계 및 내역체계는 공공 건설공사의 발주업무에 유용하게 활용되리라 기대한다.
\end{abstract}

주제어 : 다가구임대주택, 해체공사비, 예정가격, 원가구성체계

\begin{abstract}
This study is aiming at estimating the demolition cost of deterioration housing by the rational method in order to provide for the demolition and new build project of the rental multi-family housing of LH. We investigated the actual state of demolition construction and work process of small size housing, and analysed an actual condition of estimation for the demolition cost through an advice by the expert of construction cost estimate. Furthermore, the 'estimation standard for the predetermined amount', 'estimation standard for the disposal cost of construction wastes' and precedent studies in public construction work were considered. As one of results in this study, cost accounting system, breakdown system and construction cost for the demolition work based on the standard of estimate were proposed and the predetermined amount of demolition construction for the multi-family housing with 2 or 3 floors could be produced by them. Eventually, It is estimated that the demolition cost per a multi-family housing is about $18,331,000$ (won) and 104,000 (won) per floorage $\left(\mathrm{m}^{2}\right.$ ). To the details, the result indicated that the direct demolition cost needs about $14,339,000$ (won) per a multi-family housing and the consignment disposal cost of wastes needs $3,992,000$ (won) per one. The results of the study will be used as the fundamental data to estimate the project cost in the phase of budget establishment for demolition and new build project of the deteriorated rental multi-family housings, and also cost accounting system of demolition construction and breakdown system are expect to be used effectively at the ordering of public construction work.
\end{abstract}

Keywords: Rental multi-family housing, Demolition construction cost, Predetermined amount, Cost accounting system

\section{1. 서 론}

\section{1 연구 필요성 및 목적}

정부는 2004년부터 도심지 내 최저 소득계층이 현 생활권
에서 현재 수입으로 거주할 수 있도록 기존 주택을 매입하여 임대하는 사업인 '기존 주택 매입임대사업'을 시행하고 있다. 여기서 ‘기존 주택’이란「주택법」이나「건축법」에 따라 이미 사용 중인 주택을 말하며, 매입대상 주택은「건축법 시행령」

1) 토지주택연구원 수석연구원(주저자: spark72@lh.or.kr)

2) 토지주택연구원 연구위원(교신저자: leebok@lh.or.kr)

3) 토지주택연구원 연구원 
표 1. LH 다가구임대주택의 연령별 현황 ('09.12.31, 주택수 기준)

\begin{tabular}{|c|c|c|c|c|c|c|c|}
\hline 구 분 & 계 & $\begin{array}{l}\text { 5년 } \\
\text { 미만 }\end{array}$ & $\begin{array}{c}\text { 5년 } \\
\sim 10 \text { 년 }\end{array}$ & $\begin{array}{l}\text { 10년 } \\
\text { 15년 }\end{array}$ & $\begin{array}{l}\text { 15년 } \\
\text { 20년 }\end{array}$ & $\begin{array}{l}\text { 20년 } \\
\sim 25 \text { 년 }\end{array}$ & $\begin{array}{l}25 \text { 년 } \\
\text { 이상 }\end{array}$ \\
\hline 주택수(동) & 4,108 & 903 & 855 & 1,006 & 1,089 & 240 & 15 \\
\hline 비 율 $(\%)$ & 100 & 21.98 & 20.81 & 24.49 & 26.51 & 5.84 & 0.37 \\
\hline
\end{tabular}

주 : "5년 10년”은 "5년 이상에서 10 년 미만”을 의미함

별표 1에 따른 '단독주택', ‘다중주택', ‘다가구주택'과 '국민 주택규모 이하의 공동주택(다세대주택)'이다. 사업시행자인 LH는 기존 주택을 매입 및 개·보수하여 '국민임대주택'으로 공급하는 역할을 담당하고 있으며, 2004년부터 2009년까지 총 4,108개 동(총 30,020 세대)을 공급하였다. 매입, 공급한 주 택은 다가구주택과 다세대주택(이하 '다가구임대주택')이 대 부분을 차지한다.

$\mathrm{LH}$ 가 연간 6 7만호의 아파트를 공급하고 있는 점을 감안 할 때, 연간 7,000호 공급을 목표로 하는 다가구임대주택의 비중이 높은 것은 아니지만, 이 사업은 낮은 임대료로 양질의 거주환경을 제공한다는 측면에서 입주자들이 매우 환영하는 사업으로 평가받고 있다. 본 사업이 장기적으로도 긍정적인 효과를 발휘하기 위해서는 사업 시행 이후 6년여가 지난 현 시점에서 앞으로 예상되는 문제점에 대한 면밀한 진단이 필 요하다 할 수 있다.

대표적인 문제 중 하나가 주택의 노후화이다. 조사 결과, $\mathrm{LH}$ 가 공급한 다가구임대주택 중 준공 후 20 년이 지난 노후 주택 비율은 2009년 기준으로 $6.2 \%$ (255개 동) 정도에 불과하 지만, 5 년 후에는 $32.7 \%$ (1,344개 동), 10 년 후에는 $57.2 \%$ (2,350개 동)까지 누증(累增)할 것으로 나타났다(표 1).

노후주택의 누적은 곧, 철거해야 할 주택의 증가를 의미한 다. 수명이 길어짐에 따라 사용성, 기능성이 떨어져 장기간 임대되지 않는 주택1)이 증가하고 하자보수 등 유지비용이 과다하게 투입되는 주택도 증가하게 되는데, 원활한 임대사 업 수행을 위해서는 이들 노후주택을 철거하고 신축하는 방 안도 마련해야 하기 때문이다2).

한편, 기존 주택 매입임대사업은 정부 재정, 국민주택기금 등 국가 재원의 지원으로 시행하는 공공사업이다3). 따라서

1) 매입주택의 임대방법은 광역시장·도지사가 기존 주택 임대신청을 받고 임대신청자는 원하는 지역의 주택을 선택하여 입주하는 방식 이다. 따라서 주택 수명이 오래되고 노후 정도가 심한 주택은 신청 자의 입주 선호도가 떨어져 장기간 빈집으로 있는 경우가 많다.

2) 정부는 노후 다가구임대주택 철거·신축에 필요한 제도 개선을 추진 하고 있다. 2010.6월 ‘보금자리주택 업무처리지침' 제64조에 관련 조항을 신설하였는데 "준공 후 20년이 경과한 주택 중 노후화로 사 용상-기능상 불량 건축물로 판단되는 주택”과 “하자보수 등 유지비 용이 과다해 기존 주택을 철거하고 새로운 건축물을 건설하는 것이 현저한 효용 증가가 예상되는 주택"은 철거 후 신축이 가능하다.

3) 사업재원은 정부재정 $45 \%$, 국민주택기금 $50 \%$, 입주자 부담 $5 \%$ 로 구성된다.
노후 다가구임대주택의 철거 및 신축공사도 이러한 지원으로 수행해야 하기 때문에 국가 예산의 효율적 집행을 위해서는 각 공사에 투입될 비용을 정확하게 예측하는 것이 무엇보다 중요하다. 그러나 우리나라는 공공 건설사업의 신축공사에 대해서는 원가계산에 의한 예정가격 산정 기준이 잘 정비되 어, 사업의 기획이나 발주 단계에서 활용되고 있지만, 해체공 사비4)를 보다 객관적으로 예측할 수 있는 기준이나 방법은 아직 체계화되어 있지 않다. 이로 인해 몇 개 업체의 비교 견 적이나 해당 시설물에 대한 부분적인 정보 또는 과거 사례에 기초하여 공사비를 산정하는 경향도 많아, 비슷한 규모와 현 장 조건을 가진 시설물에 대해서도 발주기관, 견적부서, 업무 담당자 등에 따라 공사비 편차가 커질 수밖에 없는 상황이다.

특히 우리나라에서는 1995년 이후 해체공사비 견적기준에 관한 다수의 연구가 진행되었으나, 그 대부분이 해체공사비 견적에 필요한 표준품셈 기준의 보완 및 적용방안 제시, 발파 해체공사와 관련한 품셈 제안, 분별해체공사 도입을 전제로 한 해체물량 산정기준 및 통합 관리시스템 개발 등에 관한 것이었고, 해체공사비 예측을 위한 이론적 접근이나 원가계 산체계 구축에 관한 연구는 전무한 실정이다.

이러한 배경에서 본 연구는 LH가 공급한 다가구임대주택 해체공사를 중심으로, 예정가격 산정을 위한 원가계산체계를 구축하고, 이를 활용하여 실제 다가구임대주택에 대한 단위 면적당 공사비를 정확하게 산정하는 것을 목표로 하였다. 본 연구의 결과는 정부와 $\mathrm{LH}$ 에서 시행하는 기존 주택 매입임대 사업의 예산 수립 및 집행 과정에서 기초 자료로 활용될 뿐 아니라, 제안된 원가계산체계는 공공 건설사업의 해체공사비 발주 단계에서 유용한 자료로 활용될 수 있을 것이다.

\section{2 연구 범위 및 방법}

본 연구는 지하층 포함 3 4층 규모의 다가구주택, 다세대 주택을 대상으로 한다. 따라서 이러한 소형주택 해체현장과 전문 해체업체의 방문 조사를 통하여 공사수행 방법과 세부 작업 프로세스를 파악하였다. $\mathrm{LH}$ 를 비롯하여 민간기업, 지자 체, 철거 전문업체의 공사비 견적담당자의 면담조사를 통해 해체공사비 산정실태를 파악하였다.

실태조사 결과와 공사비 예정가격 작성에 관한 현행 법· 기준, 예규 및 선행연구 등을 분석하여 해체공사비 산정기준 수립 방향을 설정하였다. 그리고 더 정확한 해체공사 예정가 격 산정을 위하여 $\mathrm{LH}$ 의 견적전문가와 해체전문가의 자문 결 과를 종합하여 원가계산체계와 내역체계를 제안하였다. 제안 결과를 적용하여 다가구임대주택 4 개 동에 대한 해체공사비

4) 현재 우리나라의 문헌이나 실무에서는 '철거'와 '해체'가 혼용되고 있다. 그러나 친환경 공사 및 현장관리의 필요성이 커지면서 철거 (demolition)가 해체(deconstruction)의 개념으로 전환되고 있다. 따 라서 이 논문에서는 가급적 해체란 단어를 사용하였다. 
를 산정하였다. 이를 위해 4 개 주택에 대한 현장 실측도면을 작성하였고 이를 근거로 각 주택의 해체물량과 폐기물 발생 물량을 예측하여 단위면적당 공사비를 산출하였다.

\section{2. 현황조사}

\section{1 해체공사 현황}

다가구주택, 다세대주택 등 소형주택은 지상에서의 높이가 $2 \sim 3$ 층 정도에 불과하므로 $0.7 \mathrm{~m}^{3} \sim 1.0 \mathrm{~m}^{3}$ 급의 굴삭기를 이용 하면 별도의 성토작업 없이 파쇄작업을 수행할 수 있다. 따라 서 대부분 해체공사는 압쇄기가 장착된 굴삭기를 이용하여 지상에서 직접 대상주택을 파쇄시키는 방법으로 수행한다. 다만, 현장 진입도로의 폭이나 현장 면적에 따라 투입할 수 있는 장비의 대차등급5)이 달라진다. 조사결과, 소형주택 해 체에는 $0.7 \mathrm{~m}^{3} \sim 1.2 \mathrm{~m}^{3}$ 급의 장비가 주로 사용되는 것으로 나타 났으며, 대차등급이 높은 장비를 투입하는 것이 파쇄 효율성 면에서 유리하므로 작업 여건이나 공간이 충분할 경우에는 가 능한 높은 등급의 장비를 투입하고 있는 것으로 파악되었다.

해체공사는 일반적으로 (1) 공통 가설공사, (2) 석면처리 및 인력철거, (3) 장비에 의한 파쇄, (4) 폐기물 반출·현장정리 등 4 개 작업단계로 구분, 수행하고 있으며, 공사기간은 인·허가 사항 처리단계를 제외하고 약 10 일 정도가 소요된다(표 2).

(1) 가설공사 단계는 해체현장 외곽에 강관비계+분진망 등 가시설을 설치하는 단계이다.

(2) 사전 철거단계는 산업안전보건법의 관련 규정에 따라 폐석면, 슬레이트 등 지정폐기물을 처리하고 이주 시에

\section{표 2. 소형주택 해체공사 작업단계 및 소요기간}

\begin{tabular}{|c|c|c|c|}
\hline 작업 단 계 & 용 & 소요 & 기간 \\
\hline $\begin{array}{l}\text { 착공 및 } \\
\text { 대관신고 }\end{array}$ & $\begin{array}{l}\text { - 도로점용 허가신청 - 건축물 멸실신고 } \\
\text { - 특정공사 사전신고 - 비산먼지 발생신고 } \\
\text { - 폐기물 다량 배출자 신고 }\end{array}$ & \multicolumn{2}{|c|}{ 7일 } \\
\hline 가시설 설치 & $\begin{array}{l}\text { • 건물외곽 강관비계+분진망 } \\
\text { • 비산먼지 방진시설 } \quad \text { • 살수시설 }\end{array}$ & 1일 & \multirow{8}{*}{10 일 } \\
\hline 석면 보양· 해체 & - 석면 사전조사 - 석면해체 사전 신고 & 2일 & \\
\hline 내장재 인력철거 & - 내·수장재, 장판, 천장재, 창호재 등 & 1일 & \\
\hline 지상부분 철거 & • 압쇄기에 의한 파쇄작업 & 2일 & \\
\hline 폐기물 1차 반출 & - 위탁처리를 위해 수집·운반차량에 상차 & 1일 & \\
\hline 지하부분 철거 & - 압쇄기 또는 브레이커에 의한 파쇄작업 & 1일 & \\
\hline 가시설 해체 & & 1일 & \\
\hline $\begin{array}{l}\text { 폐기물 최종반출 } \\
\text { 및 현장정리 }\end{array}$ & $\begin{array}{l}\text { - 건축물대장 말소신고 - 정화조 폐쇄신고 } \\
\text { - 폐기물 배출·실적 보고 }\end{array}$ & 1일 & \\
\hline
\end{tabular}

5) 대차등급은 압쇄기, 브레이커의 작업능력에 관한 표준화된 기준이 없기 때문에 이들 장비가 장착되는 굴삭기의 버켓(bucket) 용량으 로 대체하여 등급을 설정한 것으로 현업과 건설현장에서는 일반적 으로 사용하는 용어이다.
방치된 가구, 생활쓰레기, 폐가전제품 등을 반출 가능한 범위에서 인력으로 철거하는 단계이다. 또한 내장재, 철재창호, 폐벽지, 폐장판 등을 인력으로 철거한다.

(3) 파쇄단계는 압쇄장비를 이용해 각종 쓰레기가 혼재한 상태로 대상 주택을 파쇄한 후, 폐콘크리트 덩어리와 잔재를 2차 소할파쇄하면서 폐철근 등 금속류를 추출 하는 방법으로 수행된다.

(4) 폐기물 처리단계는 건설폐기물을 중간처리업체의 수집 ·운반차량에 상차하는 단계이며, 이 작업 완료 후 현장 내 정리, 정지 작업으로 공사가 완료된다.

\section{2 해체공사비 산정 현황}

$\mathrm{LH}$ 는 신축공사의 경우, 표준품셈, 자체 실사결과 및 관련 업체의 단가자료 등 가격정보를 토대로 일위대가를 구축하고 자재비, 노임단가, 환율변동 등을 반영하여 정기적으로 조정 하고 있다. 또한 기획재정부「예정가격 작성기준」등에 기초 하여 '신축공사비 원가계산체계'를 구축하고, 이를 예정가격 산정기준으로 활용하고 있다. 그러나 해체공사에 대해서는 별도의 원가계산체계가 마련되어 있지 않으며, 공사비 산정 에 활용할 수 있는 일위대가도 상당히 제한적이다.

그림 1은 $\mathrm{LH}$ 에서 발주공사비 산정에 필요한 일위대가를 전사적으로 공유하기 위하여 운영하는 '견적정보시스템'의 구성체계이다. 해체공사와 관련한 일위대가 기준은 '토목분 야'의 '토목잡공사' 영역에 제시되어 있는데, 이 중 실제 해체 공사비 산정에 적용할 수 있는 것은 '헐기· 부수기' 항목이다. ‘헐기·부수기' 일위대가는 다시 6개 항목으로 세분되는데(표 3), 이 중 소형주택 해체공사에 적용할 수 있는 기준은 '철근콘

\begin{tabular}{|c|c|}
\hline \multicolumn{2}{|c|}{$\begin{array}{l}\text { [건축분야] [공통분야] [전기분야] [조경분야] [기계분야] [통신분야] } \\
\text { ^[토목분야] } \\
\quad \Rightarrow \text { 토목잡공사 }\end{array}$} \\
\hline $\begin{array}{l}\Rightarrow \text { 토목잡공사 } \\
\quad \text { - } 02 \text { : 헐기 및 부수기 } \\
\quad 04 \text { : 자동 세륜시설 } \\
\quad \text { • } 06 \text { : 살수 및 청소 }\end{array}$ & $\begin{array}{l}\text { - } 08 \text { : 계근대 및 무인자동화시스템 } \\
\text { - } 10 \text { : 건설기계 조립 및 해체 } \\
\text { - } 12 \text { : 축중기 }\end{array}$ \\
\hline
\end{tabular}

그림 1. LH 견적정보시스템의 일위대가 분류 체계

표 3. LH 견적정보시스템의 '헐기 및 부수기' 일위대가 (단위: 원)

\begin{tabular}{c|c|r|r|r|c}
\hline 일위대가명(규격) & 단위 & 합 계 & 재료비 & 노무비 & 경비 \\
\hline 콘크리트포장 절단(카타기) & $\mathrm{m}$ & 2,122 & 960 & 1,114 & 48 \\
\hline 콘크리트 절단 $(5 \times 50 \mathrm{~mm})$ & $\mathrm{m}$ & 2,184 & 1,022 & 1,114 & 48 \\
\hline 아스콘포장 절단(카타기) & $\mathrm{m}$ & 1,992 & 886 & 1,058 & 48 \\
\hline 아스콘포장 깨기 & $\mathrm{m}^{3}$ & 143,376 & 6,827 & 136,549 & 0 \\
\hline 슬레이트 철거 & $\mathrm{m}^{2}$ & 11,921 & 4,470 & 7,364 & 87 \\
\hline 무근콘크리트 부수기 & $\mathrm{m}^{3}$ & 198,912 & 9,472 & 189,440 & 0 \\
\hline 철근콘크리트 부수기 & $\mathrm{m}^{3}$ & 497,280 & 23,680 & 473,600 & 0 \\
\hline
\end{tabular}


크리트 부수기'와 ‘슬레이트 철거' 항목 뿐이다.

해체공사비의 체계적 산정을 위해서는 해체작업 단계와 내용에 따른 내역체계, 일위대가 등을 구축하고 적정한 견적 기준을 수립할 필요가 있다. 그러나 현재는 이러한 기준이 제 대로 정비되어 있지 않기 때문에, 비교견적이나 발주공사의 규모와 성격에 부합하는 과거 사례에 기초하여 공사비를 예 측하고 있다. 이로 인해 견적부서, 업무담당자에 따라 공사비 편차가 클 수밖에 없으며, 이러한 상황은 민간건설사나 지자 체도 크게 다르지 않았다. 전문 철거업체의 경우, 자체 일위 대가와 견적기준을 마련, 적용하고는 있으나, 이를 기준으로 일관된 공사비를 산출하기 보다는, 발주가격 내에서 낙찰 가 능성이 있는 공사비를 결정하고 이 금액을 기준으로 경험적 으로 일위대가를 조정, 제시하는 경향이 많았다.

\section{3. 선행연구 및 기준 고찰}

해체공사비는 크게 시설물에 대한 직접 철거비용과 발생 폐기물의 위탁 처리비용으로 구분된다. 따라서 이 장에서는 해체공사비와 건설폐기물 처리비용 산정에 관한 선행연구와 현행 법, 기준 등을 고찰하였다. 아울러 예정가격 산정기준 수립 방향을 설정하기 위하여 실적공사비 방식과 원가계산 방식을 비교하는 방법으로 공공 건설공사의 예정가격 적산방 식을 고찰하였다.

\section{1 해체공사비 산정 관련 선행연구}

우리나라에서는 1990년대부터 시설물 해체에 관한 다양한 연구가 수행되었지만, 대부분이 우리나라의 해체기술 수준을 선진국 수준으로 향상하기 위한 해체공법의 도입과 실용화를 위한 연구였다. 반면에, 1995년 이후 재개발-재건축사업, 주 거환경개선사업 등이 증가함에 따라 해체공사비 산정기준의 필요성이 높아지면서 이 분야의 연구가 시작되었다.

선행연구에는 주로 발파해체공사 활성화를 위한 표준품셈 기준 제안(김효진 외, 1999), 해체공사에 적용할 수 있는 기 존 표준품셈 기준을 고찰하고 문제점을 분석하여 공사비 견 적 과정에서 일관성 있게 적용하는 방안(김효진 외, 1999)을 비롯하여 기계식해체와 발파해체 공사비 비교를 통해 발파해 체공법의 활성화 시점을 전망한 연구(조태완, 2004) 등이 진 행되었다. 최근 연구로는 공동주택 아파트의 분별해체공사 도입을 목적으로 해체물량 원단위 작성과 내역체계를 구축하 기 위한 연구(김효진 외, 2005)와 해체물량 산정의 자동화 및 폐기물 처리, 재활용계획 수립 등에 관한 통합 관리시스템 개 발 연구가 진행된 바 있다(김창학 외, 2011).

이상과 같이 선행연구는 주로 해체공사비 산정에 필요한 표준품셈의 적용 방법, 아파트 해체공사에 대비한 내역체계 구축, 해체공사 전반의 통합 관리시스템 개발을 내용으로 하
였고, 2 3층 규모 소형주택에 대한 해체공사비 산출에 관한 연구는 전무한 상황이다. 본 연구에서는 이러한 소형주택을 대상으로 해체공사비 견적 과정에서 활용할 수 있는 원가계 산체계와 내역체계에 대한 실무적 제안으로 해체공사비 견적 방식을 정립하였다는 점에 차별성이 있다고 할 수 있다.

\section{2 건설폐기물 처리비 산정기준 고찰}

현행「건설폐기물 재활용 촉진에 관한 법률」제 16 조에 의 하면, 건설현장에서 발생하는 폐기물은 배출자가 “스스로 처 리”하거나 “적정 업체에 위탁처리”해야 한다. 그러나 스스로 처리하는 방법은 폐기물이 발생한 당해 현장에서만 가능하며 배출자가 직접 처리시설을 설치·운영해야 하는 등 현실적인 어려움이 많다. 따라서 아직까지는 대부분의 폐기물이 중간 처리업체에 위탁 처리되고 있는 것이 현실이기 때문에, 본 연 구에서는 위탁처리 방법을 중심으로 기준을 고찰하였다.

위탁처리비는 한국건설자원협회 '건설폐기물 처리단가'를 적용해 산정할 수 있다. 이 단가는 폐기물의 성상별로 단위량 (ton)에 대한 처리비용(원)으로 제시되기 때문에(표 4), 위탁 처리비 산정을 위해서는 시설물에 대한 건설폐기물 발생량을 예측할 필요가 있다.

발생량 예측에 관해서는 같은 협회의 '건설폐기물의 적정 처리·재활용 촉진을 위한 업무처리 요령'을 참고할 수 있다. 이 요령에서는 건설폐기물 물량을 (1) 설계도서에 의한 방법, (2) 실측에 의한 방법, (3) 배출원단위에 의한 방법, (4) 기타 방 법 중에서 시설물의 특성, 현장 조건에 맞는 최적의 방법을 적용하여 산출하도록 하고 있다.

본 연구의 대상인 노후 다가구임대주택은 신축했을 때의 도면을 확보하기 어렵고, 실측도면을 작성하여 물량을 산출 하더라도 폐기물의 다양한 특성 상 그 정확성이 담보되지 않 을 소지가 많다. 반면에 배출원단위에 근거한 방법은 우리나 라 여러 기관에서 원단위 기준을 제안한 바 있고, 실제 현업 에서도 이러한 배출원단위를 사용해 건설폐기물 발생량을 산 출하고 있다.

일반적으로 '건설폐기물 배출원단위'(이하, 발생원단위)는 신축공사는 시공면적을 해체공사는 해체공사 총 바닥면적에 대한 건설폐기물 발생량으로 산정한다.

$$
\text { 발생원단위 }=\frac{\text { 건설폐기물 발생량(ton) }}{\text { 해체공사 총 바닥면적 }\left(\mathrm{m}^{2}\right)}
$$

우리나라에서 발생원단위 연구는 1995년 이후 건설교통부(현 국토해양부), 정부출연기관 등이 주도하여 시작하였다. 연구는 주로 건축물의 신축 및 해체공사에서 발생하는 폐기물을 대상으 로 집중되었으며, 토목공사에서의 원단위 작성에 관한 구체적인 연구는 수행된 바가 없다(한국환경정책평가연구원, 2004). 


\begin{tabular}{|c|c|c|c|}
\hline 종류·성상 & \multicolumn{2}{|c|}{ 적 용 범 위 } & 적용단가 \\
\hline 건설폐재류 & \multicolumn{2}{|c|}{ 가연성건설폐기물이 제거된 상태로 콘크리트가 일부 포함되고 폐벽돌, 폐기와, 폐블럭, 토사 등 비금속광물이 혼합배출된 상태 } & 23,428 \\
\hline 건설오니 & \multicolumn{2}{|c|}{ 연약지반 안정화를 시키는 과정 중에 발생하는 무기성 오니로서 함수율 $85 \%$ 이내로 건조되어 운반 및 처리가 가능한 상태 } & 30,378 \\
\hline $\begin{array}{l}\text { 혼합 } \\
\text { 건설폐기물 }\end{array}$ & \multicolumn{2}{|l|}{ 불연성 혼합건설폐기물(폐유리, 폐타일, 폐자기 등) } & 67,000 \\
\hline $\begin{array}{l}\text { 기타 } \\
\text { 건설폐기물 }\end{array}$ & $\begin{array}{c}\text { 배출현장에서 불가피한 여건에 따라 건설폐재류에 가연성폐기물이 } 5 \% \text { 를 초과하여 } \\
\text { 혼합배출된 것 (경제적 이유 등으로 혼합배출된 것은 제외) }\end{array}$ & $\begin{array}{l}\text { 소각 } 7 \% \text { 이하 } \\
\text { 소각 } 10 \% \text { 이하 } \\
\text { 소각 } 13 \% \text { 이하 } \\
\text { 소각 } 15 \% \text { 이하 }\end{array}$ & $\begin{array}{l}41,483 \\
50,745 \\
59,984 \\
66,143 \\
\end{array}$ \\
\hline
\end{tabular}

주 : 1) 혼합폐기물의 혼합비율이 적용 혼합비율의 중간에 있을 때의 적용단가는 직선보간법에 의하여 산정한다.

2) 한국건설자원협회가 제공하는 자료에는 건설폐기물 처리단가를 배출지별로 구분하여 제시하고 있다. 본 논문에는 재건축 재개발공사(노후주택, 아파트, 빌딩 등 철거해체공사)에서 발생하는 건설폐기물의 단가만을 수록한다.

발생원단위 작성 방법은 2 가지로 대별된다. 해체현장에서 건설폐기물 발생량을 직접 계측한 결과를 분석하여 원단위를 제시하는 '직접조사방법'과 설문조사 및 선행 연구자료·문헌 을 비교, 분석함으로써 간접적으로 원단위를 산정하는 '간접 추계방법'이다.

선행 연구자료에 의하면 직접조사방법이 시간, 비용적인 면에서 간접추계방법에 비해 더 어렵지만, 직접조사방법에 의해 산출된 원단위가 건설폐기물 발생량 예측에 더 적정한 자료를 제시한다고 지적한다(홍원화 외, 2007).

건설폐기물 처리비용 예정가격을 산정하는 발주자나 업무 담당자의 입장에서 발생원단위를 선택하는 기준은 발생량 산 출 결과가 실제 발생량에 어느 수준까지 부합할 것인가에 있 을 것이다. 발주할 때 물량 예측이 잘못 될 경우 공사 수행과 정에서의 잦은 설계변경으로 이어질 수 있기 때문이다.

표 5는 우리나라에서 수행된 발생원단위 작성에 관한 주요 연구사례를 나타낸 것으로, 직접조사방식으로 발생원단위를 작성한 연구는 총 3 건이다. 이 중 이 진행한 “주거용 건축물 해체 전·후 건설폐기물 발생량 비교·분석을 통한 건설폐기 물 발생원단위 작성 연구(홍원화 외, 2007)"는 직접조사방식 으로 진행한 가장 최근의 연구라 할 수 있다. 특히 본 연구에 서 제안한 발생원단위는 실제 다가구주택, 다세대주택에 대 하여 해체 전·후의 폐기물 발생량 측정 결과만으로 작성되었 기 때문에 실제 발생량에 가장 근접한 원단위를 제공한다고 볼 수 있다(표 6).

\section{3 공공 건설공사 예정가격 적산 방식}

국가 재원이 투입되는 공공 건설공사에서 적정한 예정가 격의 결정은 제한된 예산의 효율적 집행을 위해 중요한 과제 이다. 아울러 공공 건설공사에서 발주기관이 산정하는 예정
표 5. 건설폐기물 발생원단위 관련 선행연구 사례

\begin{tabular}{|c|c|c|}
\hline 구분 & 연 구 과 제 명 & 연구기관 \\
\hline \multirow{6}{*}{$\begin{array}{l}\text { 간접 } \\
\text { 추계 } \\
\text { 방식 }\end{array}$} & $\begin{array}{l}\text { 건축물 폐재류의 적정처리 및 재활용방안 } \\
\text { 연구(1995) }\end{array}$ & 서울시정개발연구원 \\
\hline & $\begin{array}{l}\text { 건설폐기물 재활용 가이드라인 설정 및 } \\
\text { 재활용 촉진방안(1995) }\end{array}$ & 한국자원재생공사 \\
\hline & $\begin{array}{l}\text { 건설산업 폐기물의 리싸이클링 시스템 및 } \\
\text { 재활용기술 개발(1995) }\end{array}$ & 충남대(건설교통부) \\
\hline & 건설폐기물 처리 및 재활용방안 I (1997) & 주택연구소(주택공사) \\
\hline & 건설공사 표준품셈(2003) & 건설기술연구원(국토부) \\
\hline & $\begin{array}{l}\text { 건설폐기물 분리배출 및 발생원단위 산정 } \\
\text { 등에 관한 연구(2004) }\end{array}$ & 환경정책평가연구원 \\
\hline \multirow{3}{*}{$\begin{array}{r}\text { 직접 } \\
\text { 추계 } \\
\text { 방식 }\end{array}$} & 구조물 해체공법에 관한 연구 I (1996) & 주택연구소(주택공사) \\
\hline & $\begin{array}{l}\text { 부천 상동지구 발생폐기물 재활용 처리 } \\
\text { 방안에 관한 연구(2000) }\end{array}$ & 건설기술연구원(토지공사) \\
\hline & $\begin{array}{l}\text { 주거용 건축물 해체 전·후의 건설폐기물 } \\
\text { 발생량 비교·분석을 통한 건설폐기물 } \\
\text { 발생원단위 작성에 관한 연구(2007) }\end{array}$ & $\begin{array}{l}\text { 주택도시연구원(국토부) } \\
\text { 경북대학교 }\end{array}$ \\
\hline
\end{tabular}

주 : 169 170의 내용포함 재구성(홍원화 외, 2007)

표 6. 주거용 건축물의 건설폐기물 발생원단위

(단위 : ton $/ \mathrm{m}^{2}$ )

\begin{tabular}{c|c|c|c|c|c|c}
\hline 구 분 & $\begin{array}{c}\text { 콘크리트 } \\
\text { 류 }\end{array}$ & $\begin{array}{c}\text { 철물· } \\
\text { 철재류 }\end{array}$ & 목재류 & $\begin{array}{c}\text { 합성 } \\
\text { 수지류 }\end{array}$ & $\begin{array}{c}\text { 혼합 } \\
\text { 폐기물 }\end{array}$ & 계 \\
\hline $\begin{array}{c}\text { RC조 } \\
\text { (비율:\%) }\end{array}$ & $\begin{array}{c}1.510 \\
(91.85)\end{array}$ & $\begin{array}{c}0.061 \\
(3.69)\end{array}$ & $\begin{array}{c}0.009 \\
(0.56)\end{array}$ & $\begin{array}{c}0.002 \\
(0.14)\end{array}$ & $\begin{array}{c}0.061 \\
(3.74)\end{array}$ & $\begin{array}{c}1.664 \\
(100)\end{array}$ \\
\hline $\begin{array}{c}\text { 블록조 } \\
\text { (비율:\%) }\end{array}$ & 0.906 & 0.022 & 0.032 & 0.001 & 0.060 & 1.021 \\
$(88.72)$ & $(2.17)$ & $(3.14)$ & $(0.14)$ & $(5.83)$ & $(100)$ \\
\hline 조적조 & 0.896 & 0.024 & 0.001 & 0.001 & 0.039 & 0.967 \\
(비율:\%) & $(92.68)$ & $(2.50)$ & $(0.65)$ & $(0.14)$ & $(4.03)$ & $(100)$ \\
\hline
\end{tabular}

가격은 계약금액의 상한 구속, 입찰금액의 적정성 판별, 계약 금액의 조정 등에 주요한 기준으로도 작용한다.

$\ulcorner$ 국가를 당사자로 하는 계약에 관한 법률」에서는 예정가 
격을 “입찰 또는 계약체결 전에 낙찰자 및 계약금액의 결정 기준으로 삼기 위하여 미리 작성·비치하여 두는 가액"으로 정의하고(시행령 제 2 조), 예정가격은 (1) 거례실례가격, (2) 원 가계산가격, (3) 실적공사비, (4) 견적가격 등으로 결정하도록 규정하고 있다(시행령 제9조). 또한 이 법령의 하위 규정인 기획재정부「예정가격 작성기준」에 의하면, 공공 건설공사의 예정가격 산정방식은 실적공사비에 의한 방식과 표준품셈을 기초로 한 원가계산방식으로 대별할 수 있다.

실적공사비 적산제도는 2004년 정부의 '실적공사비 회계 예규' 제정으로 시행되었다. 실적공사비에 의한 방식은 건설 공사 계약목적물의 세부 공종에 관하여 재료비, 직접노무비, 직접경비의 전부나 일부가 포함된 시공단위당 가격을 이미 수행한 공사의 계약단가 또는 원·하도급자간 실제 거래가격 등을 활용하여 예정가격을 산정하는 방식이다.

이 방식은 현행 공공공사 예정가격의 거품 제거, 적정 수 준에서의 예정가격 형성을 통한 실제 공사비에 근접하는 입 찰가격 형성, 발주처 및 설계회사의 예정가격 산정업무의 경 감 등의 장점을 갖고 있다. 그러나 실적단가 결정기준이 계약 단가인가 준공단가인가 하는 모호한 점이 있으며, 실적자료 의 축적기간 및 축적량 등에 따른 신뢰성과 안전성, 설계변경 시 가격조정의 기준 및 일부 공종에만 적용이 가능하다는 점 등이 문제점으로 제기되고 있다.

표준품셈에 의한 원가계산방식은 공사비를 재료비, 노무비 및 경비로 구분하고 작업순서별 비용을 일일이 산출해 전체 비용을 계산하는 방식이다. 이 방식은 1968년 표준품셈이 제 정된 이후 지금까지 공공과 민간의 공사비 적산 분야에 일익
을 담당하고 있다.

그러나 표준품셈은 대표적, 보편적인 공법과 현장조건에 기초한다는 특성 상 신기술, 신공법 등의 신속한 반영이 곤란 하고 가속화되는 건설기술의 다양성을 적기에 흡수하는 데도 한계가 있다. 또한 현장여건에 따라 조정하여 적용할 수 있는 여지가 있음에도 경직되게 적용되고 있다는 것도 문제점으로 지적되고 있다.

한편, 유일현 외(2005)은 표준품셈에 의한 원가계산방식과 실적공사비 방식을 회계학적인 관점에서 비교하였는데, 원가 계산방식이 공사비 산정절차는 상대적으로 복잡한 반면에, 정확도는 높다고 지적하였다(표 7).

그리고 김찬규 외(2006)은 표준품셈에 의한 원가계산방식 이 다양하고 복잡한 현장조건을 가지는 건설회사에 매우 적 합한 방식이며, 예정가격 산정방식으로는 더 정확한 방법으 로서 모든 건설공사에 적용이 가능하다는 장점이 있다고 지 적한 바 있다.

정부는 2004년 이후 실적공사비 제도를 시행하면서 공공 건설공사의 발주공사비 산정을 권고하고 있다. 그러나 해체 분야는 공사계약 단가에 대한 누적자료가 많지 않고, 업체 간 과열 경쟁에 의한 계약공사비 편차가 클 뿐만 아니라, 다단계 하도급으로 공사비 집계가 어렵다는 점 등의 한계점이 있다. 따라서 실적공사비 방식에 의한 해체공사 예정가격 산정이 활성화되기 위해서는 충분한 시간이 필요할 것으로 보인다.

이상의 내용을 종합할 때, 표준품셈에 의한 원가계산방식 이 몇 가지 문제점이 있다 하더라도 실적공사비 방식에 비해 더 정확한 방식이며, 다양한 현장조건을 갖고 있는 건설회사

\section{표 7. 원가계산방식과 실적공사비방식의 비교}

\begin{tabular}{|c|c|c|}
\hline 항 목 & 표준품셈에 의한 원가계산방식 & 실적공사비방식 \\
\hline 관련 회계예규* & $2200.04-105-8$ & $2200.04-157$ \\
\hline 정확도 & 높다 & 상대적으로 낮다 \\
\hline 가격산정 방식 & 시공공법의 진행순서에 따라 순차적으로 합하여 산정 & 목적물의 수량에 보정된 실적비용을 곱하여 산정 \\
\hline 계획 및 설계단계 & 도면완성 이전에 가격산정 불가 & 가격축적 방식에 따라서 가능 \\
\hline 산정 절차 & 상대적으로 복잡하다 & 상대적으로 간단하다 \\
\hline 공법 선택 & 표준공법을 적용토록 지침 & 시공사의 기술력에 따라 선택 \\
\hline 적용 가능성 & 거의 모든 공종에 적용 가능 & 일부 공정에만 적용 가능 \\
\hline 내역서 작성 방식 & 설계자 및 발주기관에 따라 상이 & 표준 분류체계인 ‘수량산출기준’에 의해 내역서 작성 통일 \\
\hline 설계변경 & 품목 조정방식, 지수 조정방식 & 지수 조정방식(공사비 지수 적용) \\
\hline
\end{tabular}

주 : * 2005년 당시의 관련 회계예규이며, 2011년 현재는 기획재정부 회계예규(2200.04-160-8, 2010.10.22)로 통합됨 
에 더 적합한 방식이라는 기존 연구자들의 평가를 감안하면, 현재로서는 해체공사 예정가격 산정에는 표준품셈에 기초한 원가계산방식을 적용하는 것이 더 합리적인 결과를 기대할 수 있을 것으로 사료된다.

\section{4. 원가계산방식에 의한 해체공사비 산정 기준}

표준품셈에 의한 원가계산방식으로 공사비 예정가격을 산 정할 때는 기획재정부 회계예규인「예정가격 작성기준」의 규정에 따라야 한다. 이에 의하면 공사비 예정가격은 재료비, 노무비, 경비, 일반관리비, 이윤 등 5 개 비목으로 구분하여 계 산한다. 또한 회계예규에서는 각 비목에 대한 세부비목의 결 정과 물량산출 기준을 다음과 같이 규정하고 있다.

(1) 재료비, 노무비, 경비 각각에 대한 세부비목과 그 물량 (재료량, 노무량, 소요량) 산출은 계약목적물의 규격서, 설계서에 의하거나 2 개 업체 이상의 최근년도 원가계 산 자료를 근거로 산정하여야 한다.

(2) 세부비목 및 소요물량은 계약목적물의 내용과 특성을 고려해 계약목적을 완성할 수 있는 합리적인 방법으로 결정해야 한다.

이상 규정을 종합하면, 공공 건설공사의 예정가격은 대상 시설물에 대한 설계도면에 근거하여, 대상 공사를 완수할 수 있는 합리적인 방법으로 재료비, 노무비 및 경비에 대한 세부 비목을 결정하고, 각 세부비목에 대한 소요물량을 산출하여 최종 가격을 작성하는 절차로 진행하게 된다.

현재 LH에서는 이 회계예규를 토대로 아파트 신축공사에 일관성 있게 적용할 수 있는 예정가격 원가계산체계와 재료 비, 노무비, 경비에 대한 세부비목을 정비하여 견적기준으로 활용하고 있다(표 8). 그러나 해체공사비에 대해서는 아직 자 체적인 원가계산체계나 비목별 세부비목 구성에 대한 기준이 마련되지 않은 상황이다.

따라서 본 연구에서는 다가구임대주택 등 소형주택 해체 공사의 수행 특성과 세부 작업공종을 반영하여 해체공사를 합리적으로 완성할 수 있는 공사비 원가계산체계, 내역체계 및 일위대가 등을 다음과 같이 제안하였다.

\section{1 해체공사비 원가계산체계 제안}

2.1절에 기술한 대로, 다가구임대주택과 같은 소형주택은 압쇄기, 브레이커 등 기계장비를 이용하여 해체공사를 수행 한다. 따라서 이 절에서는 해체전문가와 견적전문가 자문을 통하여 표 8의 신축공사비 원가계산체계를 토대로 소형주택 기계해체공사의 현장 특성 및 작업 내용을 반영한 예정가격 원가계산체계를 표 9 와 같이 제안하였다.

재료비 비목에서는 해체 과정에서 유상 판매가 가능한 고 철이나 수목 등이 발생하기 때문에 신축공사와는 달리 유가
표 8. LH의 신축공사비 원가계산체계

\begin{tabular}{|c|c|c|c|c|}
\hline \multirow{7}{*}{$\begin{array}{l}\text { 신 } \\
\text { 축 } \\
\text { 공 } \\
\text { 사 } \\
\text { 비 }\end{array}$} & \multirow{5}{*}{ 총 원 가 } & & 재료비 & 지급재료비, 도급재료비 \\
\hline & & & 노무비 & 직접노무비, 간접노무비 \\
\hline & & 공사원가 & $\begin{array}{l}\text { 경 비 } \\
\text { (25개 } \\
\text { 항목) }\end{array}$ & $\begin{array}{l}\text { 기계경비, 가설비, 운반비 } \\
\text { 전력비 등, 산업안전보건관리비 } \\
\text { 산재보험료, 고용보험료 } \\
\text { 국민건강보험, 국민연금보험 } \\
\text { 폐기물처리비, 환경보전비 } \\
\text { 품질관리비, 안전점검비 } \\
\text { 수도광열비, 여비·교통통신비 } \\
\text { 건설근로자퇴직공제부금비 } \\
\text { 하도급대금지급보증서발급수수료 } \\
\text { 공사이행보증서발급수수료 } \\
\text { 기타경비(7개 항목) }\end{array}$ \\
\hline & & 일반관리비 & & \\
\hline & & 이 윤 & & \\
\hline & 손해보험료 & & & \\
\hline & 부가가치세 & & & \\
\hline
\end{tabular}

표 9. 소형주택 해체공사비 원가계산체계(제안)

\begin{tabular}{|c|c|c|c|c|}
\hline \multirow{7}{*}{$\begin{array}{l}\text { 해 } \\
\text { 체 } \\
\text { 공 } \\
\text { 사 } \\
\text { 비 }\end{array}$} & \multirow{5}{*}{ 총 원 가 } & & 재료비 & $\begin{array}{l}\text { 직접재료비, 간접재료비 } \\
\text { 유가물매각비 }(\triangle)\end{array}$ \\
\hline & & & 노무비 & 직접노무비, 간접노무비 \\
\hline & & 공사원가 & $\begin{array}{l}\text { 경 비 } \\
\text { (14개 } \\
\text { 항목) }\end{array}$ & $\begin{array}{l}\text { 기계경비, 가설비, 운반비 } \\
\text { 전력비 등, 산업안전보건관리비 } \\
\text { 산재보험료, 고용보험료, } \\
\text { 국민건강보험, 국민연금보험 } \\
\text { 폐기물처리비, 환경보전비 } \\
\text { 건설근로자퇴직공제부금비 } \\
\text { 하도급대금지급보증서발급수수료 } \\
\text { 공사이행보증서발급수수료 }\end{array}$ \\
\hline & & 일반관리비 & & \\
\hline & & 이 윤 & & \\
\hline & 손해보험료 & & & \\
\hline & 부가가치세 & & & \\
\hline
\end{tabular}

물 매각비 차감 항목을 추가하였다. 반면에, 해체공사 작업공 종은 신축공사에 비해 상대적으로 단순하기 때문에 경비를 구성하는 세부비목에서 품질관리비, 안전점검비, 수도광열 비, 기타경비 7 개 항목 등 11 개 항목을 제외함으로써 신축공 사 25 개에서 해체공사 14 개 항목으로 조정하였다.

\section{2 해체공사비 내역체계 및 일위대가}

다가구임대주택 해체공사비 내역체계는 공사 현장의 작업 공종 및 프로세스를 반영하여 공통 가설공사비, 석면처리비, 직접파쇄비, 폐기물처리비 및 고재 매각비 등 5 개 항목으로 분류하였다(그림 2).

예정가격 산정을 위해서는 각 항목에 대한 비용을 산정할 수 있는 일위대가 자료가 필요하다. 본 연구에서는 현재 $\mathrm{LH}$ 현업부서에서 다양한 형태로 산재되어 있는 해체공사 관련 


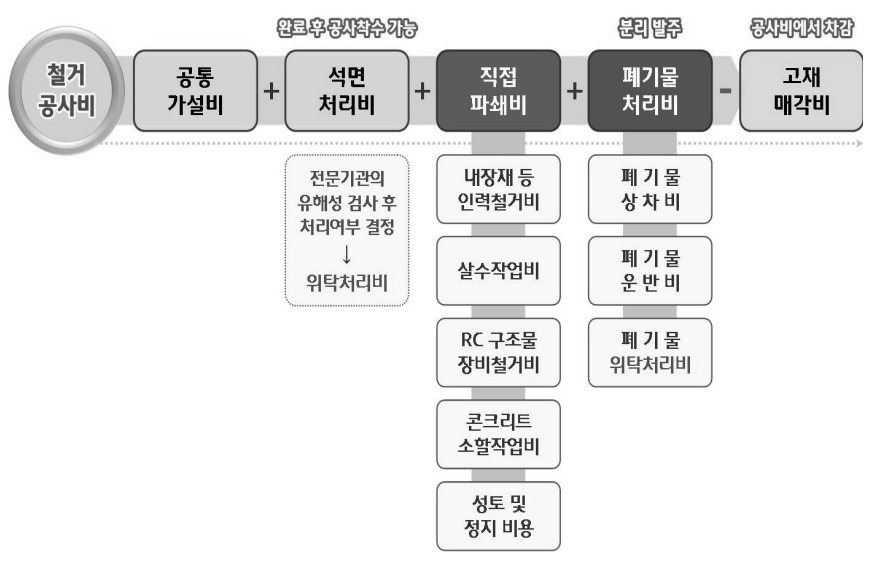

그림 2. 소형주택 해체공사 내역체계 구성

표 10. 해체공사비 일위대가 구성체계

\begin{tabular}{|c|c|c|}
\hline 대 분 류 & 중 분 류 & 소 분 류 \\
\hline 가설공사 & $\begin{array}{l}\text { 가설울타리 } \\
\text { 강관비계+분진방지막 }\end{array}$ & $\mathrm{H}=6 \mathrm{~m}$, 강관외줄, 방진막 \\
\hline $\begin{array}{l}\text { 내 장 재 } \\
\text { 철거작업 }\end{array}$ & $\begin{array}{l}\text { 내장 천정재 철거 } \\
\text { 내장 창호재 철거 } \\
\text { 내장 바닥재 철거 }\end{array}$ & \\
\hline $\begin{array}{l}\text { 구 조 물 } \\
\text { 파쇄작업 }\end{array}$ & $\begin{array}{l}\mathrm{RC} \text { 구조물 장비철거 } \\
\text { 무근구조물 장비철거 } \\
\mathrm{RC} \text { 구조물 장비철거 } \\
\text { 무근구조물 장비철거 } \\
\text { 살수작업 } \\
\text { 철근 및 잡철물 절단 }\end{array}$ & $\begin{array}{l}\text { 브레이커 + 백호우 } 0.7 \mathrm{~m}^{3}(\mathrm{t}: 30 \mathrm{~cm} \text { 미만) } \\
\text { 브레이커 + 백호우 } 0.7 \mathrm{~m}^{3}(\mathrm{t}: 30 \mathrm{~cm} \text { 미만) } \\
\text { 압 쇄 기 + 백호우 } 1.0 \mathrm{~m}^{3}(\mathrm{t}: 30 \mathrm{~cm} \text { 미만) } \\
\text { 압 쇄 기 + 백호우 } 1.0 \mathrm{~m}^{3}(\mathrm{t}: 30 \mathrm{~cm} \text { 미만) }\end{array}$ \\
\hline $\begin{array}{l}\text { 폐 기 물 } \\
\text { 처리작업 }\end{array}$ & $\begin{array}{l}\text { 일반폐기물 상차 } \\
\text { 일반폐기물 운반 }\end{array}$ & \\
\hline 현장정리 & $\begin{array}{l}\text { 성토 및 땅고르기 } \\
\text { 현장정리 }\end{array}$ & \\
\hline
\end{tabular}

일위대가를 수집, 정리하고, 일위대가의 시장 부합성을 해체 전문가와 견적전문가 자문을 통해 검토, 조정하여 소형주택 해체공사에 적용할 수 있는 26개 항목의 일위대가표를 작성 하였다. 표 10 은 일위대가표의 구성체계이다.

다만, 근래 폐석면의 적정처리에 관한 기준이 강화되면서 이에 대한 일위대가도 필요한 상황이지만, 다가구임대주택과 같은 소형주택에서는 발생량이 극히 소량이고, 전문기관의 유해성 검사 결과 위탁처리가 필요할 때는 처리비용을 별도 계상해야 하기 때문에 본 연구에서는 제외하였다.

\section{5. 다가구임대주택 해체공사 예정가격 산출}

본 연구에서 제안한 예정가격 원가계산 및 내역체계, 일위 대가를 적용하여 실제 다가구임대주택 4 개 동에 대한 해체공 사 예정가격을 산출하였다.

산출 대상은 바닥면적 합계가 $168.3 \sim 183.1 \mathrm{~m}^{2}$ 이며, 조적조 수직부재와 철근콘크리트 테두리보 및 슬래브로 구성된 변형
표 11. 해체공사비 산정을 위한 대상주택 5 개동 현황

\begin{tabular}{c|c|c|c|c}
\hline 구 분 & 대지면적 $\left(\mathrm{m}^{2}\right)$ & 총 바닥면적 $\left(\mathrm{m}^{2}\right)$ & 층수 & 구조 \\
\hline 주택 1 & 173 & 174.1 & & \\
\cline { 1 - 3 } 주택 2 & 171 & 168.3 & \multirow{3}{*}{ 지상 2층 } & $\begin{array}{c}\text { 벽돌조, } \\
\text { 슬래브지붕 }\end{array}$ \\
\hline 주택 3 & 170 & 183.1 & & \\
\hline 주택 4 & 156 & 178.3 & & \\
\hline
\end{tabular}

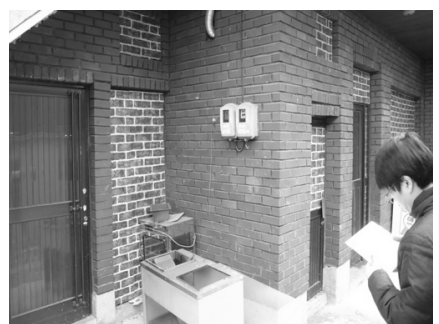

(a) 주택 외부 조사

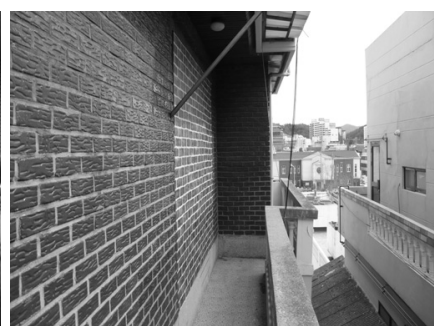

(b) 2 층 외부복도 조사
그림 3. 해체공사비 산정을 위한 대상주택 현장 실측조사

가구식 구조를 가진, 지상 2층 규모 주택이다(표 11).

주택을 선정할 때, 준공 후 20 년이 지난 다가구임대주택 총 255 개동의 바닥면적 합계의 평균 값인 $177 \mathrm{~m}^{2}$ 를 기준으로 $\pm 10 \mathrm{~m}^{2}$ 영역 $\left(167 \sim 187 \mathrm{~m}^{2}\right)$ 에 해당하는 35 개 동을 선정하고, 이 중에서 입주자가 많지 않아 실사가 원활한 주택을 무작위로 선정함으로써 본 연구에서 산출한 예정가격이 대표성을 가질 수 있도록 하였다.

\section{1 실측 조사 및 도면 작성}

기획재정부 회계예규는 공사 예정가격 작성방법으로 설계 도면에 근거한 방법을 권고하고 있다. 그러나 다가구임대주 택을 포함한 대부분의 일반 건축물은 준공 후 20 년이 지나면 신축할 때의 도면을 확보할 수 없는 것이 현실이다. 따라서 대상 주택 4 개 동에 대한 현장 실측조사를 수행하여 도면을 작성하였다.

조사 방법은 조사원들이 직접 줄자, 레이저 측정기 등을 이용하여 주택을 구성하는 부재 및 자재 등을 육안 조사하고 필요한 경우 천정재 및 벽지 등을 제거하면서 치수를 실측하 였다(그림 3).

주택의 구성재를 표 12 와 같이 11 종의 폐기물로 분류하고, 각각에 해당하는 부위를 조사하였다. 욕조, 싱크대, 세면기, 양변기, 정화조, $\mathrm{PVC}$ 물탱크 등은 본 공사를 수행하기 전에 인력으로 철거하는 부분이므로 조사 항목에서 제외하였다. 그리고 현장 실측조사에서 판단할 수 없는 부위에 대해서는 도면작성 과정에서 유사한 규모의 주택에 대한 신축도면을 참고하였다. 대상 주택 4 개동에 대하여 각 측 평면도, 정면도, 배면도, 좌·우측면도를 작성하였으며, 이 논문에서는 주택 1 의 도면만을 수록한다(그림 4). 


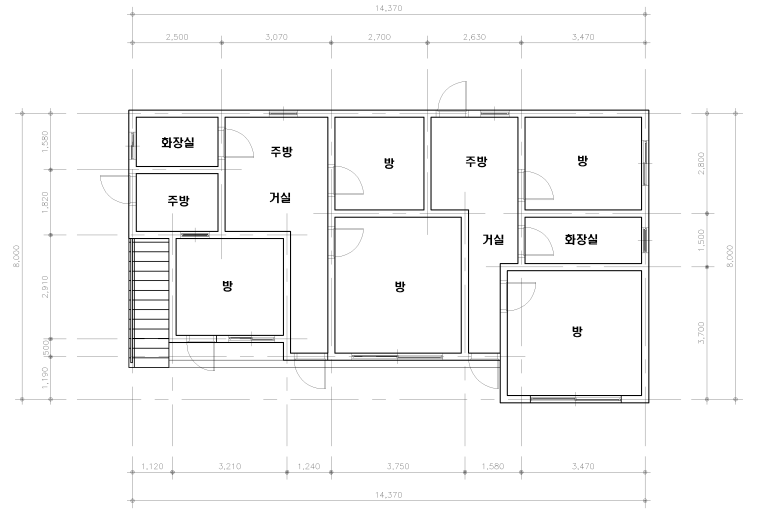

(a) 1 층 평면도

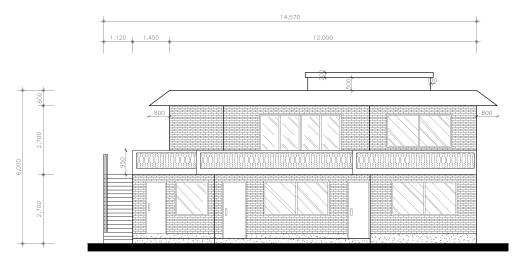

(c) 정면도

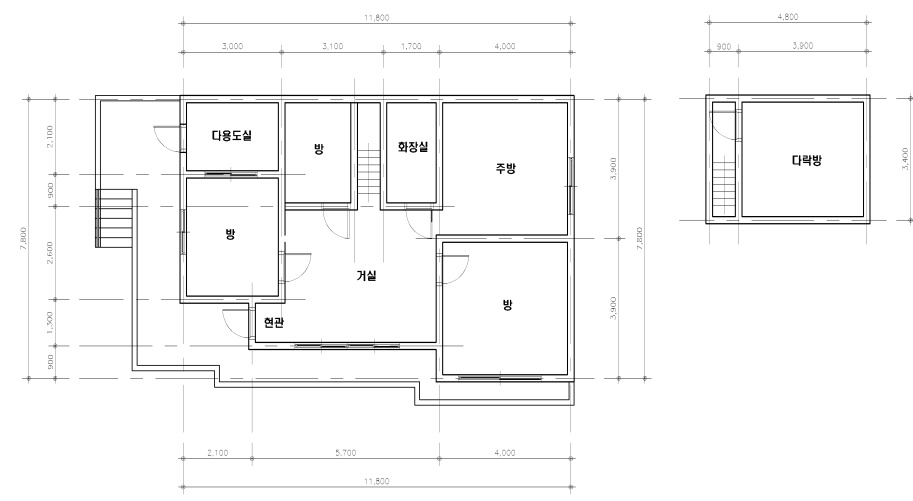

(b) 2층 평면도

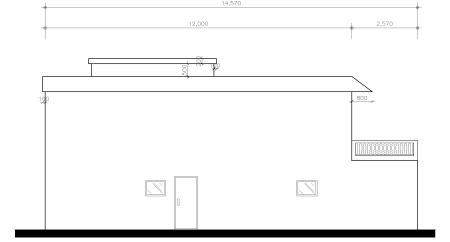

(d) 배면도

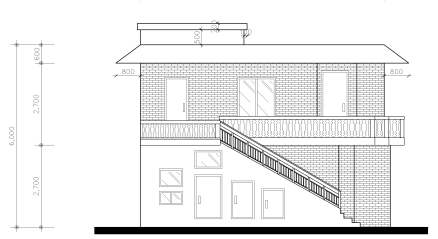

(e) 좌측면도

그림 4. 다가구임대주택의 현장 실측도면(주택 1)

표 12. 실측 대상주택 구성재의 재료별 조사부위

\begin{tabular}{|c|c|c|}
\hline \multicolumn{2}{|c|}{ 구성재의 종류 } & \multirow{2}{*}{ 조 사 부 위 } \\
\hline 대분류 & 소분류 & \\
\hline \multicolumn{2}{|c|}{ 폐콘크리트 } & 테두리보, 기초, 슬래브, 계단, 바닥판, 파라펫 \\
\hline \multirow{3}{*}{ 폐벽돌 } & 시멘트벽돌 & 외벽 \\
\hline & 적벽돌 & 외벽 \\
\hline & 치장벽돌 & 외벽 \\
\hline 폐블록 & 시멘트블록 & 내벽, 담장 \\
\hline \multirow{3}{*}{ 폐모르터 } & 미장모르터 & 외벽, 내벽, 옥상 \\
\hline & 방수모르터 & 옥상바닥 \\
\hline & 바닥인조석 & 계단바닥, 외부복도, 현관바닥 \\
\hline \multicolumn{2}{|c|}{ 폐타일 } & 화장실, 주방벽면, 현관바닥 \\
\hline \multicolumn{2}{|c|}{ 폐유리 } & 창호 \\
\hline 폐기와 & 지붕기와 & 지붕 \\
\hline \multirow{2}{*}{ 폐목재 } & 각재 & 목재창호, 걸레받이 \\
\hline & 판재 & 내부문, 천장 \\
\hline \multirow{4}{*}{ 폐합성수지 } & 스티로폼 & 외벽, 천장 \\
\hline & $\mathrm{PE}$ 필름 & 옥상바닥 \\
\hline & 연질PVC & 비닐장판 \\
\hline & 경질PVC & $\mathrm{PVC}$ 설비배관 \\
\hline 폐벽지 & 마감벽지 & 내벽 \\
\hline \multirow{3}{*}{ 폐금속 } & 철재 & 계단난간, 대문, 문, 환기창, 전기설비, 배관류 \\
\hline & 알루미늄 & 창호틀 \\
\hline & 황동 & $\mathrm{SD}$ 경첩, 논슬립 \\
\hline
\end{tabular}

\section{2 실측도면에 의한 해체물량 산출}

실측도면을 근거로 해체물량을 예측하였다. 이 때 주택을 구성하는 부재 및 자재의 형태에 따라 체적이나 면적을 계산 하고, 이 결과에 건축재료 단위중량을 적용하여 물량을 산출
하였다(표 13, 표 14).

테두리보는 현장 실측조사에서 정확하게 확인할 수 없는 부위이므로 '건축물의 구조내력에 관한 기준'을 참고하여 벽 두께의 1.5 배로 적용하였다.

대부분 소형주택의 기초는 연속기초로 시공되고 있지만 현장 실측이 불가하므로 매트기초로 가정하고, 두께는 최하 층 벽 두께의 $120 \%$ 인 $240 \mathrm{~mm}$ 를 적용하였다.

모르터에 대해서는 미장모르터는 내벽 $18 \mathrm{~mm}$, 외벽과 옥 상층은 $24 \mathrm{~mm}$, 옥상 층의 방수모르터는 $10 \mathrm{~mm}$ 를 적용하였다.

창호는 기성 제품을 사용한 것으로 가정하여, 창은 3 가지 타입 $(1,200 \times 600,1,800 \times 1200,2,400 \times 2,000)$ 을 적용하였고, 문 은 내벽에 접한 문 $(800 \times 2,000)$ 과 외벽에 접한 문 $(900 \times 2,000)$ 그리고 대문 $(1,800 \times 2,000)$ 으로 구분, 적용하였다.

$\mathrm{PVC}$ 설비배관의 물량은 현장 계측이 불가능하므로 ' $\mathrm{LH}$ 2010 공사비 분석자료'의 '난방배관용 X-L 파이프'에 대한 원단위 기준인 단위면적 $\left(\mathrm{m}^{2}\right)$ 당 $3.8 \mathrm{~m}$ 를 적용하였다.

철근콘크리트 부재에 매립된 철근, 계단 논슬립, 설비배관 및 계단 난간의 철재 등은 현장 계측이 불가능하므로 표 6 의 발생원단위 중 ‘철물·철재류 항목'을 적용, 산출하였다.

이상의 방법으로 주택 4 개 동에 대한 해체물량을 산출하였 고, 주택 1에 대한 산출 결과는 표 15 표 17에 제시한다.

\section{3 일위대가 적용 기준}

해체공사는 현장의 입지조건 및 작업여건에 따라 공사의 난이도 및 공사비 규모가 크게 달라진다. 본 연구에서는 해체 
표 13. 대상주택의 각 부재 및 재료별 측정 방법

\begin{tabular}{|c|c|c|}
\hline 부 재 & 실 측 방 법 & 비 고 \\
\hline 기 초 & 전체 길이 $(\mathrm{L}) \times$ 폭 $(\mathrm{w}) \times$ 높이 $(\mathrm{h})$ & \multirow{8}{*}{ 체 적 } \\
\hline 계 단 & 전체 길이 $(\mathrm{L}) \times$ 폭 $(\mathrm{w}) \times$ 두께 $(\mathrm{d})$ & \\
\hline 바 닥 & 전체 면적 $(\mathrm{S}) \times$ 두께 $(\mathrm{d})$ & \\
\hline 담 장 & 전체 길이 $(\mathrm{L}) \times$ 두께 $(\mathrm{d}) \times$ 높이 $(\mathrm{h})$ & \\
\hline 벽 체 & 전체 길이 $(\mathrm{L}) \times$ 전체 높이 $(\mathrm{H}) \times$ 두께 $(\mathrm{d})$ & \\
\hline 기둥 및 보 & 폭 $(\mathrm{w}) \times$ 두께 $(\mathrm{d}) \times$ 높이 $(\mathrm{h}) \times$ 개소 & \\
\hline 슬래브 & 전체 면적(S)× 두께(d) & \\
\hline 천정틀 & 체적 $(\mathrm{M}) \times$ 개소 & \\
\hline 지 붕 & 전체 면적(S) & \multirow{2}{*}{ 면 적 } \\
\hline 창 호 & 전체 면적(S) & \\
\hline 기 타 & 각 재료 별 측정 & 체적, 면적 \\
\hline
\end{tabular}

표 14. 건축용 재료의 단위체적 및 단위면적 중량

\begin{tabular}{c|c|c|c}
\hline 구 분 & 단 위 & 중 량(ton) & 비 고 \\
\hline 콘크리트 & $\mathrm{m}^{3}$ & 2.3 & 체 적 \\
\hline 블 록 & $\mathrm{m}^{3}$ & 1.68 & 체 적 \\
\hline 벽 돌 & $\mathrm{m}^{3}$ & 1.9 & 체 적 \\
\hline 모 르 터 & $\mathrm{m}^{3}$ & 2.1 & 체 적 \\
\hline 도기 및 유리편류 & $\mathrm{m}^{3}$ & 2.5 & 체 적 \\
\hline 목 재 류 & $\mathrm{m}^{3}$ & 0.5 & 체 적 \\
\hline 목재창호 & $\mathrm{m}^{2}$ & 0.008 & 면 적 \\
\hline 철재창호 & $\mathrm{m}^{2}$ & 0.0095 & 면 적 \\
\hline 철재도어 & $\mathrm{m}^{2}$ & 0.034 & 면 적 \\
\hline 기 와 & $\mathrm{m}^{2}$ & 0.048 & 면 적 \\
\hline 슬레이트 & $\mathrm{m}^{2}$ & 0.038 & 면 적 \\
\hline 합성수지류 & $\mathrm{m}^{2}$ & 0.002 & 면 적
\end{tabular}

대상 다가구임대주택이 일반 주거지역에 위치한 일상적인 조 건을 가지며, $0.7 \mathrm{~m}^{3}$ 급 압쇄장비를 투입한다는 가정 하에 일 위대가를 적용하였다.

\subsection{1 공통 가설비}

공통 가설비는 해당현장 외곽에 강관외줄비계와 방진망을 설치하는 조건으로 비용을 산정하였다. 강관외줄비계에 대한 품은 현행 표준품셈에 기준이 없기 때문에 $\mathrm{LH}$ 의 품을 적용 하였고, 방진막의 설치·철거 품은 건설공사 표준품셈 2-11의 ‘방진망 설치 및 철거' 품을 적용하였다.

소형주택 해체공사는 공사기간이 통상 10 일 이내이므로 일반적인 건설현장에 적용하는 '조립식 가설사무소 및 창고', '가설 화장실 손료' 등 비용은 계상하지 않았다.

\subsection{2 내장재 등 인력철거 비용}

인력철거 비용은 천정재, 창호재, 바닥재 철거비용 및 각종 철재류 분리비용 등으로 구분할 수 있다. 이 중 철근·잡철물 등 철재류 분리 비용은 이 작업이 소할파쇄 작업과 병행하여 진행되기 때문에 소할작업비에 반영하였다. 천정재, 창호재
표 15. 체적에 기초한 해체물량 산출 결과(주택 1)

\begin{tabular}{|c|c|c|c|c|}
\hline \multicolumn{2}{|c|}{ 구성재 종류 } & \multirow{2}{*}{ 부위 } & \multirow{2}{*}{ 체적 $\left(\mathrm{m}^{3}\right)$} & \multirow{2}{*}{ 중량(ton) } \\
\hline 대분류 & 소분류 & & & \\
\hline \multirow{5}{*}{\multicolumn{2}{|c|}{ 폐콘크리트 }} & 테두리보 & 6 & 13.8 \\
\hline & & 기초 & 36.3 & 83.5 \\
\hline & & 슬래브 & 42.5 & 97.8 \\
\hline & & 계단 & 8 & 18.4 \\
\hline & & 파라펫 & 1.4 & 3.2 \\
\hline \multirow{3}{*}{ 폐벽돌 } & 시멘트벽돌 & 외벽 & 38.6 & 73.3 \\
\hline & 적벽돌 & 외벽 & 13.7 & 26 \\
\hline & 치장벽돌 & 외벽 & 0.3 & 0.6 \\
\hline \multirow{2}{*}{ 폐블록 } & \multirow{2}{*}{ 시멘트블록 } & 내벽 & 17.1 & 28.7 \\
\hline & & 담장 & 10.8 & 18.1 \\
\hline \multirow{7}{*}{ 폐모르터 } & \multirow{3}{*}{ 미장모르터 } & 외벽 & 4.6 & 9.7 \\
\hline & & 내벽 & 9 & 18.9 \\
\hline & & 옥상 & 1.9 & 4 \\
\hline & 방수모르터 & 옥상바닥 & 0.8 & 1.7 \\
\hline & \multirow{3}{*}{ 바닥인조석 } & 계단바닥 & 0.2 & 0.4 \\
\hline & & 외부복도 & 0.6 & 1.3 \\
\hline & & 현관바닥 & 0.1 & 0.2 \\
\hline \multirow{3}{*}{\multicolumn{2}{|c|}{ 폐타일 }} & 화장실 & 0.6 & 1.5 \\
\hline & & 주방벽면 & 0.3 & 0.75 \\
\hline & & 현관바닥 & 0.01 & 0.03 \\
\hline \multicolumn{2}{|c|}{ 폐유리 } & 창호 & 0.24 & 0.6 \\
\hline
\end{tabular}

표 16. 면적에 기초한 해체물량 산출 결과(주택 1)

\begin{tabular}{|c|c|c|c|c|}
\hline \multicolumn{2}{|c|}{ 구성재 종류 } & \multirow{2}{*}{ 부위 } & \multirow{2}{*}{ 면적 $\left(\mathrm{m}^{2}\right)$} & \multirow{2}{*}{ 중량(ton) } \\
\hline 대분류 & 소분류 & & & \\
\hline \multirow{4}{*}{ 폐목재 } & \multirow{2}{*}{ 각재 } & 목재창호 & 10.5 & 0.08 \\
\hline & & 걸레받이 & 5.4 & 0.04 \\
\hline & \multirow{2}{*}{ 판재 } & 내부문 & 19.2 & 0.15 \\
\hline & & 천장 & 194.3 & 1.55 \\
\hline \multirow{5}{*}{ 폐합성수지 } & \multirow{2}{*}{ 스티로폼 } & 외벽 & 182 & 0.36 \\
\hline & & 천장 & 194.3 & 0.39 \\
\hline & $\mathrm{PE}$ 필름 & 옥상층 바닥 & 78.4 & 0.16 \\
\hline & 연질PVC & 비닐장판 & 166.1 & 0.33 \\
\hline & 경질PVC & $\mathrm{PVC}$ 설비배관 & 10.4 & 0.02 \\
\hline 폐벽지 & 내부마감벽지 & 내벽 & 425.1 & 0.85 \\
\hline \multirow{3}{*}{ 폐금속 } & \multirow{2}{*}{ 철재 } & 대문 & 3.6 & 0.12 \\
\hline & & 문 & 16.2 & 0.55 \\
\hline & 알루미늄 & 창호틀 & 9.4 & 0.09 \\
\hline
\end{tabular}

표 17. 발생원단위를 적용한 해체물량 산출 결과(주택 1)

\begin{tabular}{|c|c|c|c|c|}
\hline \multicolumn{2}{|c|}{ 구성재 종류 } & \multirow{2}{*}{ 부위 } & \multirow{2}{*}{$\begin{array}{c}\text { 총 바닥면적 } \\
\left(\mathrm{m}^{2}\right)\end{array}$} & \multirow{2}{*}{ 중량(ton) } \\
\hline 대분류 & 소분류 & & & \\
\hline \multirow{3}{*}{$\begin{array}{l}\text { 고재 및 } \\
\text { 폐철물 }\end{array}$} & 폐철근 & $\begin{array}{c}\text { 테두리보, 기초 } \\
\text { 슬래브, 계단, } \\
\text { 파라펫 }\end{array}$ & \multirow{3}{*}{174.1} & \multirow{3}{*}{4.18} \\
\hline & 폐철재 & $\begin{array}{c}\text { 환기창, 계단난간 } \\
\text { 전기설비류, } \\
\text { 설비배관 }\end{array}$ & & \\
\hline & 황동 & SD경첩, 논슬립 & & \\
\hline
\end{tabular}


및 바닥재의 철거 품은 표준품셈의 '21-1 해체철거공사 중 건 축물 구조체별 철거'의 해당 부위별 품을 적용하였다.

\subsection{3 직접 파쇄비}

주택의 직접파쇄비는 ‘2.1 해체공사 현황’에 언급한 소형 주택 해체방법과 '4.2의 내역체계(그림 2)'에 따라서 다음과 같이 계상하였다.

(1) $\mathrm{RC}$ 구조물 장비철거비

전체 파쇄작업을 $0.7 \mathrm{~m}^{3}$ 급 압쇄기로 수행하는 것으로 비 용을 계상하였다. 다만, 현 표준품셈에는 $0.7 \mathrm{~m}^{3}$ 압쇄기 품 기준이 없으므로 토목부문의 " $10-20$ 대형브레이커 + 굴삭기 $0.7 \mathrm{~m}^{3}(\mathrm{t}: 30 \mathrm{~cm}$ 미만)" 의 품을 적용하였다.

(2) 살수비

표준품셈 토목부문 “2-17 '비산먼지 발생 억제를 위한 살수’의 품을 적용하였다. 16,000liter 용량의 살수차로 현장작업 과정에서 살수하는 품이다.

(3) 철재류 절단작업비

폐철근, 잡철물 등의 절단작업은 산소절단을 기준으로 하여 표준품셈 건축부문의 "21-1 해체철거공사의 3. 헐 기 및 부수기” 중 ‘나. 기계사용' 품을 적용하였다.

(4) 폐콘크리트 소할작업비

「폐기물 관리법」에 의하면, 폐콘크리트 덩어리는 지름 $100 \mathrm{~mm}$ 이하의 크기로 반출해야 한다. 따라서 1차 파쇄 작업으로 발생한 철거잔재 소할비용을 표준품셈 토목 부문의 “ $10-20$ 대형브레이커 + 굴삭기 $0.7 \mathrm{~m}^{3}(\mathrm{t}: 30 \mathrm{~cm}$ 미 만)" 의 품을 적용해 계상하였다. 이 비용에 여기에 앞 서 언급한 철물·철재류 분리비용을 포함시켰다.

(5) 폐기물 상차·운반 및 현장정리 비용

소할파쇄 작업 완료 후 현장에 집적된 잔재는 폐기물 수집·운반차량에 실어 적정 처리업체로 반출한 다음 현장 정지, 성토 등 마무리 작업이 진행된다. 이 때, 상 차비용은 $0.7 \mathrm{~m}^{3}$ 급 굴삭기 품을, 운반비용은 $15 \mathrm{ton}$ 덤프 트럭 $(30 \mathrm{~km})$ 을 기준으로 계상하였다. 성토 및 정지 비용 은 “ $0.7 \mathrm{~m}^{3}$ 급 굴삭기 + 보통인부” 품을 적용하여 비용을 계상하였다.

(5) 고재 등 매각비

해체공사에서는 부재에 매립된 철근이나 논슬립, 계단 및 옥상 난간, 현장에 식재된 수목 등 유상으로 판매할 수 있는 폐기물이 발생한다. 연구 대상인 다가구임대주 택에서는 고철 이외의 유가물은 없는 것으로 확인되어, 250,000 원/ton의 매각비용을 재료비에서 차감하였다.

\section{4 다가구임대주택 해체공사 예정가격 산출 결과}

본 연구에서는 해체공사 예정가격을 가설비, 인력철거비 및 직접 파쇄비 등 현장에서 직접 수행하는 작업에 소요되는
비용 즉, ‘직접 철거비용’과 폐기물의 ‘위탁 처리비용'으로 구분하여 산출하였다.

\subsection{1 직접 철거비}

4개 다가구임대주택에 대한 직접 철거비용은 연구 제안한 '해체공사 원가계산체계(표 9)'와 '일위대가 기준(5.3절)'을 이용하여 산출하였다. 이 때, 간접노무비, 안전관리비, 일반 관리비 및 이윤 등 관련 법령에서 계상비율을 규정하고 있는 항목은 법적 상한 값을 적용하였다.

표 18 은 주택 1 의 직접 철거비용 산출 결과로 총 13,784 천 원이 투입될 것으로 나타났으며, 주택 2 4는 표 21과 같이 13,568 천원 $\sim 15,644$ 천원 정도인 것으로 나타났다.

\subsection{2 건설폐기물 위탁 처리비}

위탁 처리비용을 산출하기 위해서는 3.2에서 고찰한 바와 같이 폐기물 발생 물량을 중량 단위로 예측해야 한다. 폐기물 처리단가가 단위(ton)당 비용으로 고시되기 때문이다.

본 연구에서는 다가구임대주택의 폐기물 발생량을 가장 최근에 작성된 발생원단위 기준인 표 6 을 적용하여 예측하였 으며, 그 결과는 표 19에 제시한다.

위탁 처리비용은 폐기물 종류·성상별 예측물량에 '2011년

표 18. 다가구임대주택 직접 철거비용 산출 결과 (주택 1)

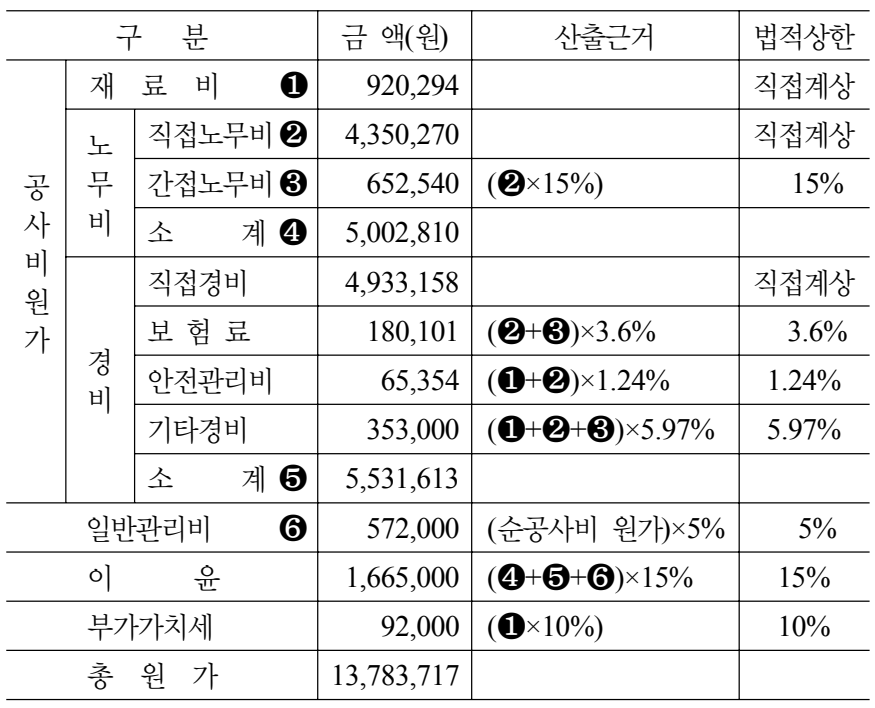

표 19. 건설폐기물 발생량 예측 결과

(단위 : ton)

\begin{tabular}{|c|c|c|c|c|c|c|c|}
\hline \multirow[b]{2}{*}{ 구 분 } & \multirow{2}{*}{$\begin{array}{c}\text { 콘크리트 } \\
\text { 류 } \\
\text { (ton) }\end{array}$} & \multirow{2}{*}{$\begin{array}{l}\text { 철물. } \\
\text { 철재류 } \\
\text { (ton) }\end{array}$} & \multicolumn{4}{|c|}{ 기타 건설폐기물 (ton) } & \multirow{2}{*}{$\begin{array}{c}\text { 총 } \\
\text { 발생량 } \\
\text { (ton) }\end{array}$} \\
\hline & & & 목재류 & $\begin{array}{l}\text { 합성수 } \\
\text { 지류 }\end{array}$ & $\begin{array}{c}\text { 혼합폐 } \\
\text { 기물 }\end{array}$ & 소계 & \\
\hline & & 4.177 & & 0.174 & 6788 & & \\
\hline 주택 2 & 150.770 & 4.038 & & 0.168 & 6.563 & 8 & 161.707 \\
\hline 주택 3 & 161067 & 4.395 & & 0.183 & 1.141 & & $1 / 5.909$ \\
\hline 주택 4 & 159.748 & 4.279 & 0.178 & 0.178 & 6.953 & 7.310 & 171.337 \\
\hline
\end{tabular}


표 20. 건설폐기물 위탁처리 비용

(단위 : 원)

\begin{tabular}{c|c|c|c}
\hline 구 분 & 건설폐재류 & 기타 건설폐기물 & 총 계 \\
\hline 주택 1 & $3,653,359$ & 296,008 & $3,949,366$ \\
\hline 주택 2 & $3,532,238$ & 286,194 & $3,818,432$ \\
\hline 주택 3 & $3,843,751$ & 311,434 & $4,155,185$ \\
\hline 주택 4 & $3,742,572$ & 303,236 & $4,045,809$ \\
\hline 평 균 & $3,692,980$ & 299,218 & $3,992,198$ \\
\hline
\end{tabular}

표 21. 해체공사 예정가격 산출 결과

(단위 : 원)

\begin{tabular}{|c|c|c|c|c|c|}
\hline \multirow{2}{*}{ 구 분 } & \multirow{2}{*}{$\begin{array}{c}\text { 총 } \\
\text { 바닥면적 }\end{array}$} & \multirow{2}{*}{$\begin{array}{c}\text { 직접 } \\
\text { 철거비용 }\end{array}$} & \multirow{2}{*}{$\begin{array}{c}\text { 폐기물 } \\
\text { 위탁처리비 }\end{array}$} & \multicolumn{2}{|c|}{ 해체공사 예정가격 } \\
\hline & & & & 총 공사비 & 단위면적당 \\
\hline 주택 1 & $174.04 \mathrm{~m}^{2}$ & $13,783,717$ & $3,949,366$ & $17,733,083$ & 101,891 \\
\hline 주택 2 & $168.27 \mathrm{~m}^{2}$ & $13,568,247$ & $3,818,432$ & $17,386,679$ & 103,326 \\
\hline 주택 3 & $183.11 \mathrm{~m}^{2}$ & $15,643,626$ & $4,155,185$ & $19,798,811$ & 108,125 \\
\hline 주택 4 & $178.29 \mathrm{~m}^{2}$ & $14,360,403$ & $4,045,809$ & $18,406,212$ & 103,237 \\
\hline 평 균 & $175.93 \mathrm{~m}^{2}$ & $14,338,998$ & $3,992,198$ & $18,331,196$ & 104,145 \\
\hline
\end{tabular}

주: 지상에서 $0.7 \mathrm{~m}^{3}$ 급 장비를 사용하여 철거하는 조건이며, 생활쓰레기 처리비용은 제외한 금액임

건설폐기물 처리단가(표 4)'를 곱하여 산정하였는데, 이 때 콘크리트류는 건설폐재류의 단가인 23,428원/ton을 적용하였 고, 목재류, 합성수지류, 혼합폐기물 등 기타 건설폐기물은 '가연성 폐기물이 $7 \%$ 이하'인 폐기물로 보고 41,483 원/ton을 적용하였다. 표 20 은 비용산출 결과로서 주택 1 은 3,949천원, 주택 2 4는 3,818천원 4,155천원의 비용이 필요할 것으로 나타났다.

결과적으로, ‘직접 철거비용’과 ‘위탁 처리비용’을 합산한 다가구임대주택 4개 동에 대한 해체공사 예정가격은 표 21과 같이 평균 18,331 천원으로 산정되었고, 단위면적 기준으로는 104 천원의 비용이 소요되는 것으로 나타났다.

\section{6. 결 론}

본 연구는 $\mathrm{LH}$ 다가구임대주택 철거·신축사업에 대비하여 노후주택에 대한 해체공사비를 합리적 근거에 의해 예측하는 것을 목표로 하였다. 이를 위해 표준품셈에 기초한 해체공사 원가계산체계, 내역체계 및 일위대가를 제안하고, 이를 활용 하여 4개 다가구임대주택에 대한 해체공사 예정가격을 산출 하였으며, 그 결과는 다음과 같다.

1. 공사비 예측에 관한 선행연구 결과와 우리나라의 해체 공사비 견적 실태를 감안할 때, 해체공사비 산정은 실적 공사비 방식 보다 표준품셈에 기초한 원가계산 방식으 로 산정하는 것이 더 정확한 결과를 예측할 수 있을 것 으로 사료된다.
2. 해체공사 예정가격은 현장에서 직접 수행하는 작업에 필요한 '직접 철거비용'과 폐기물 '위탁 처리비용'으로 구분하여 산출하는 것이 합리적이다.

3. 다가구임대주택 해체공사에는 직접 철거비 14,339천원/ 동, 폐기물 위탁처리비 3,992천원/동 정도가 소요될 것 으로 나타났다.

4. 다가구임대주택 1 개 동당 총 해체공사비는 18,331 천원, 바닥면적 기준으로는 104 천원 $/ \mathrm{m}^{2}$ 원으로 예측되었다.

일반적으로 건설공사비를 산정하는 방법은 견적의 수준에 따라 상세견적기법과 개략견적기법으로 구분된다. 상세견적 기법은 실시설계가 완료되어 시설물의 설계정보가 확정된 후 도면에 기초하여 공사비를 산정하는 방법을 말한다. 반면에, 개략견적기법은 사업의 기획 및 타당성 분석이나 초기 설계 단계에서 해당 시설물의 부분적인 정보나 과거 사례에 기초 하여 공사비를 예측하는 방법으로, 단계 및 수행주체에 따라 다양한 목적을 갖고 수행된다(한승현 외, 2009).

연구에서 제안한 다가구임대주택 해체공사비는 1 차적으로 다가구임대주택의 철거·신축사업의 예산편성 단계에서 활용 하기 위해 산출한 것으로 이러한 측면에서는 개략공사비의 성격을 가진다. 반면, 본 연구에서는 대상 주택의 실측도면을 상세하게 작성하고 이 도면에 근거하여 공사비 예정가격을 산출하였기 때문에 상세공사비의 성격도 함께 가진다고 볼 수 있다. 특히, 본 연구는 해체공사비 산정체계 구축에 관한 연구가 거의 수행되지 않은 상황에서, 공공 공사에 적용할 수 있는 예정가격 작성기준을 체계적으로 제안하고 이를 실제 주택에 적용하여 공사비 산출을 시도한 최초의 연구라는데 그 의의가 있다.

다만 본 연구는 다음과 같은 면에서 한계를 갖는다.

첫째, 석면 처리비용을 고려하지 않았기 때문에 폐슬레이 트 지붕 등 석면 함유자재가 많은 주택에 대해 본 연구에서 제시한 공사비 예측결과를 적용하는 데는 한계가 있다. 전문 기관의 석면 함유자재에 대한 검사 결과, 유해성 석면이 있는 주택은 석면 위탁처리비를 별도 계상해야 한다.

둘째, 다양한 지역에 독립적으로 산재되어 있는 다가구임 대주택의 특성 상, 해체공사는 주변 가옥이 있는 상태로 진행 하게 된다. 따라서 다가구임대주택 해체공사는 대규모 단지 해체공사와 비교할 때 생활폐기물이 거의 발생하지 않는 것 으로 볼 수 있다. 이에 본 연구에서 예측한 공사비에는 생활 폐기물 처리비용이 반영되어 있지 않기 때문에 주거환경개선 사업 등 대단위 지역의 주택을 집단적으로 철거하는 공사에 본 연구결과를 적용하는 데는 한계가 있다. 이러한 경우 생활 폐기물 발생량을 예측하고 이에 따른 처리비용을 추가, 반영 하여야 한다. 


\section{참고문헌}

1. 국토해양부(2010), 「보금자리주택 업무처리지침」.

2. 기획재정부(2010), 「예정가격 작성기준(예규, 2200.04-160-8)」.

3. 대한주택공사(2008), 「2008 견적기준 감독실무」.

4. 한국건설기술연구원(2010), 「건설공사 표준품셈」.

5. 김효진, 이철규(1999), 「발파해체공사의 품 기준 설정 연구」, 대 한주택공사.

6. 김효진, 박성식, 신재완(2000), 「해체공사의 설계 및 견적기준 정립 연구」, 대한주택공사.

7. 김효진, 박성식, 김종환(2005), 「공동주택 철거잔재의 활용성 향 상을 위한 해체공사 시스템 개발」, 한국건설교통기술평가원.

8. 한국건설자원협회(2008), 「건설폐기물의 적정처리·재활용 촉진 을 위한 업무처리 요령」.

9. 한국환경정책평가연구원(2004), 「건설폐기물 분리배출 및 발생 원단위 산정 등에 관한 연구」.
10. 조태완(2004), “해체공사비 비교분석을 통한 발파해체 공법 전망”, 「한국건설관리학회 논문집」, 5(4): 130 138.

11. 김창학(2011), “해체폐기량 산정 및 통합관리를 위한 시스템 개 발”, 「한국건설관리학회 논문집」, 12(1): 133 140.

12. 홍원화, 손병훈, 정응혁, 정종석(2007) "주거용 건축물 해체 전. 후의 건설폐기물 발생량 비교 · 분석을 통한 건설폐기물 발생원 단위 작성 연구”, 「대한건축학회논문집」, 23(10): 169 170.

13. 유일현(2005), “건설공사의 표준품셈과 실적공사비 원가계산 방법의 비교연구", 「충남대학교 회계논집」, 6(1).

14. 김찬규, 강윤식, 권석원(2006), "건설공사 원가산정의 표준품셈 과 실적공사비 비교 연구”, 「한국건설관리학회 학술발표대회 논문집」, $82 \sim 85$.

15. 한승현, 곽수남, 김두연, 김병일, 최석진(2009), “가용정보를 활 용한 기획 및 설계초기 단계의 도로공사비 예측모델”, 「한국건 설관리학회 논문집」, 10(4): 87 100. 